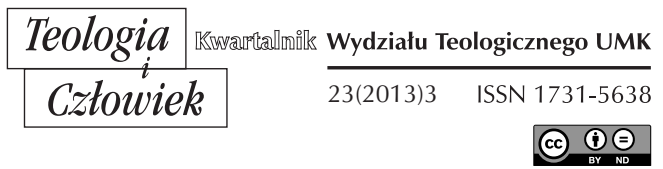

KS. WALDEMAR RAKOCY $C M^{*}$

LUBLIN

\title{
CZY UDZIELONY DUCH WYGASZA FUNKCJĘ PRZYKAZAŃ BOŻYCH? PRZYCZYNEK DO PAWŁOWEJ PNEUMATOLOGII
}

DOI: http://dx.doi.org/10.12775/TiCz.2013.029

Podstawą niniejszego artykułu są Pawłowe wypowiedzi o końcu Prawa Mojżeszowego, którego szczytem był dekalog. Powołując się na autorów, wskażemy, jak apostoł mógł rozumieć ów koniec, lecz główną uwagę skupimy na pastoralnym zastosowaniu owych wypowiedzi. Mówiąc inaczej, zweryfikujemy ich prawdziwość w codziennym życiu chrześcijanina.

\section{APOSTOK PAWEK O KOŃCU PRAWA MOJŻESZOWEGO}

W Listach apostoła Pawła znajdują się wypowiedzi o ustaniu Prawa Mojżeszowego. W Rz 10, 4 pisze on, że Chrystus jest kresem Prawa. Grecki termin $\tau \dot{\lambda} \lambda o \varsigma$ znaczy „cel”, ale również „koniec"1; osiągnięcie

" Ks. prof. dr hab. Waldemar Rakocy CM - kierownik Katedry Egzegezy Pism Apostolskich NT na Wydziale Teologii Katolickiego Uniwersytetu Lubelskiego Jana Pawła II.

${ }^{1}$ W. Bauer, A Greek-English Lexicon of the New Testament and Other Early Christian Literature, London 1979, s. 811-812. 
celu równa się bowiem końcowi pewnego procesu. Jeżeli celem Prawa jest Chrystus, to Jego przyjście wypełnia je ${ }^{2}$ i tym samym wyznacza mu koniec. Wyraźniej zostało to stwierdzone w Ga 3,19. Apostoł pisze tam, że Prawo Mojżeszowe zostało dane do chwili przyjścia Potomka (Chrystusa), któremu udzielono obietnicy. Greckie åxpıs oũ (,aż do”) wskazuje na konkretny moment w historii - ma znaczenie punktowe ${ }^{3}$. Prawo pełni swą funkcję do chwili przyjścia Chrystusa. Jego wygaśniecie jest powiązane z daną obietnicą, którą stanowi Duch Święty, o czym jest mowa kilka wierszy wcześniej (w. 14). Prawo zostało zatem dane do momentu przyjścia Chrystusa i wylania Ducha Bożego. Innymi słowy z przyjściem Odkupiciela i udzielonym Duchem wypełniło swą misję.

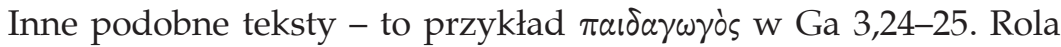
owego $\pi \alpha \iota \delta a \gamma \omega \gamma o ̀ s$, czyli niewolnika doprowadzającego syna swego pana do szkoły ${ }^{4}$, ustawała z chwilą osiągnięcia przez niego określonego wieku.

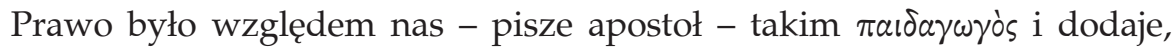
że z chwilą nastania czasu wiary, tj. przyjścia Chrystusa, nie jesteśmy mu więcej poddani. Oto kolejny tekst, w którym stwierdza się, że Prawo pełniło swą funkcję względem nas do czasu przyjścia Chrystusa ${ }^{5}$. W Rz Paweł napisze - z kolei - o swych chrześcijańskich adresatach: „Nie jesteście [więcej] poddani Prawu, lecz łasce” $(6,14)$. Zostaliśmy wyzwoleni z mocy Prawa6. Wszystkie przytoczone teksty wskazują na Chrystusa jako Tego, który wyznacza kres Prawu Mojżeszowemu. W jednym z nich jest to jednocześnie powiązane z udzielonym Duchem.

Autorzy dyskutują, jak należy rozumieć powyższe stwierdzenia. Czy pisząc o ustaniu Prawa, apostoł miał na myśli całe Prawo Mojżeszowe czy może jego jeden lub drugi wymiar. Ich opinie skupiają się wokół owych dwóch rozwiązań7. Za ustaniem jedynie części Prawa (np. wymiar

2 Zob. np. R. Jewett, Romans, Minneapolis 2007, s. 619-620.

3 J. H. Moulton, A Grammar of New Testament Greek, Edinburgh 1963, t. III, s. 276.

${ }^{4}$ Platon, Prawa, IV, 208C.

${ }^{5}$ Zob. R. N. Longenecker, Galatians, WBC 41, Dallas 1990, s. 146-149.

${ }^{6}$ Szerzej R. Jewett, dz. cyt., s. 411-412.

7 Zob. H. J. Schoeps, Paul: The Theology of the Apostle in the Light of Jewish Religion History, Philadelphia 1961; A. von Dülmen, Die Theologie des Gesetzes bei Paulus, Stuttgard 1968; H. Hübner, Das Gesetz bei Paulus. Ein Beitrag zum Werden der paulinischen Theologie, FRLANT 119, Göttingen 1978; E. P. Sanders, Paul, the Law, and the Jewish People, Minneapolis 1983; H. Räisänen, Paul and the Law, WUNT 29, Tübingen 1983; R. B. Hays, The Faith of Jesus Christ: An Investigation of the Narrative Substructure of Galatians 3.1-4.11, Chico 1983; L. Gaston, Paul and the Torah, Vancouver 1987; S. Westerholm, 
kultyczny) przemawia nadal obowiązujące prawo moralne (cytowani Hübner i Räisänen). Przykazania dekalogu, jak „,nie zabijaj!”, „nie cudzołóż” czy „nie kradnij” stale obowiązują. Większość jest jednak zdania, że wprawdzie nie przestają obowiązywać normy moralne, to ustaje cały porządek religijny i zbawczy oparty na Prawie Mojżeszowym. Nowy porządek zbawczy w Chrystusie wyznacza kres staremu. Nie zaprzecza jego pojedynczym zapisom, jak przykazania dekalogu, ale kładzie kres Prawu jako instrumentowi zbawienia. W tym duchu wyraża się autor Listu do Hebrajczyków: „A to, co się przedawnia, bliskie jest zniknięcia” $(8,13)$. Ustaje zatem całe Prawo Mojżeszowe, ale jego pojedyncze zapisy żyją w Ewangelii. Wydaje się, że wypowiedź Pawła odnosi się do Prawa w jego całości, a nie tylko do jednego z jego wymiarów. W przypadku przytoczonych wcześniej tekstów z Ga apostoł używa rodzajnika (ó vónos). Kiedy to czyni, ma na myśli prawie zawsze całe Prawo

Sama literatura rabiniczna, tj. Talmud Babiloński, zawiera przekaz o tym, że z przyjściem Mesjasza wygaśnie Tora9. Talmud dzieli historię ludzkości na trzy okresy, tj. chaosu, Prawa i Mesjasza, z których każdy ma trwać dwa tysiące lat. Jak Prawo kładzie kres chaosowi, tak Mesjasz - Prawu. Przejście od jednego okresu do drugiego oznacza koniec wcześniejszego. Apostoł wyraża podobną myśl pięć wieków wcześniej.

Właściwe uchwycenie myśli apostoła wymaga przedstawienia jego poglądu na temat samego Prawa Mojżeszowego. Uczynimy to $\mathrm{w}$ telegraficznym skrócie. Otóż w tym, co dotyczy wprowadzenia człowieka w zbawczą relację z Bogiem, owo Prawo wg Pawła jest całkowicie bezsilne. Jego zadaniem było stawienie człowiekowi przed oczy jego wykroczeń (Rz 3,20b; 7,7), lecz nie zaradzenie im. Sprawa przedstawia się podobnie po dzień dzisiejszy. Każdy, kto przeprowadza w oparciu o przykazania rachunek sumienia, dochodzi zawsze do tego samego wniosku, tzn. że jest grzesznikiem. Przykazania nie uświadamiają człowiekowi świętości, lecz grzeszność. Kolejnym krokiem jest przystąpienie do sakramentu

Israel's Law and the Church's Faith: Paul and His Recent Interpreters, Grand Rapids 1988; T. R. Schreiner, The Law and Its Fulfillment: A Pauline Theology of Law, Grand Rapids 1993; F. Thielman, Paul and the Law: A Contextual Approach, Downers Grove 1994; J. D. G. Dunn (red.), Paul and the Mosaic Law, WUNT 89, Tübingen 1996; tenże, The Theology of Paul the Apostle, London-New York 2003; F. Watson, Paul, Judaism, and the Gentiles. Beyond the New Perspective, Grand Rapids [MI] - Cambridge [U.K.] 2007.

${ }^{8}$ Zob. W. Rakocy, 'Nomos' $i$ 'ho nomos' w Listach Pawłowych, BibAn 1/58 (2011), s. $171-178$.

${ }^{9}$ Sanh, 97a. 
pojednania, co dowodzi, że przykazania nie mają mocy uwolnić nas od grzechów. Na drodze ich zachowywania nikt zatem nie wysłuży sobie przystępu do Boga, ponieważ w ich świetle każdy jawi się jako grzesznik. Stąd posługiwanie oparte na Prawie (przykazaniach) prowadzi ku śmierci (2 Kor 3,7) i potępieniu (w. 9). Tak niedoskonała rzeczywistość, obnażająca ludzki grzech i niezdolna mu zaradzić, chociaż pełni funkcję w perspektywie ostatecznego rozwiązania w Chrystusie, nie może być trwała, lecz przejściowa. Autor Listu do Hebrajczyków napisze o przymierzu synajskim i powiązanym z nim Prawie: „Gdyby bowiem owo pierwsze [przymierze] było doskonałe, nie szukano by miejsca na drugie" $(8,7)$. Z powodu takiego poglądu na Prawo apostoł był atakowany. Skoro w Chrystusie wieścił koniec Prawa, nie rozumiejąc, $w$ jakim sensie pojmował ów koniec, zarzucano $\mathrm{mu}$, że odrzuca przykazania i tym samym zachęca do grzeszenia. Broni się zatem: „Czyż to znaczy, iż mamy grzeszyć, dlatego że nie jesteśmy poddani Prawu, lecz łasce? Żadną miarą!" (Rz 6,15). Niegrzeszenie (w sensie relatywnym, nie dosłownym) nie jest jednak wynikiem przyjęcia przykazań, lecz łaski, o czym będzie mowa w kolejnym punkcie.

\section{ZASTOSOWANIE TEOLOGICZNO-PASTORALNE PAWŁOWYCH WYPOWIEDZI O KOŃCU PRAWA MOJŻESZOWEGO}

W tym miejscu interesuje nas praktyczny wymiar owych stwierdzeń, czyli ich zastosowanie $\mathrm{w}$ życiu chrześcijanina. Zanim do tego przejdziemy, zostaną podane trzy zasady hermeneutyczne, które pomogą zrozumieć zaproponowane odczytanie myśli apostoła:

1. Zrozumienia Pawłowego poglądu na temat Prawa Mojżeszowego nie można opierać na pojmowaniu owego Prawa przez Żydów (ST), ponieważ w świetle objawienia NT jego funkcja jawi się inna. Owo rozumienie może pełnić rolę pomocniczą. Podstawą myślenia Pawła jest Chrystus (Ga 1,11-12), a nie ST, czyli prawda poznana w naszym Panu, a nie to, co wiedział uprzednio jako Żyd. Jego wcześniejsze przekonania doznały bowiem radykalnej przemiany ${ }^{10}$. Dlatego wypracowane na etapie

${ }^{10}$ Novum Ewangelii nie polega na dopełnieniu przekonań starotestamentowych, lecz na zaproponowaniu czegoś nowego, co wyrasta ze ST, ale jednocześnie go przerasta. Wybrzmiewa to $\mathrm{w}$ nazywaniu przez apostoła rzeczywistości nowotestamentowej nowym stworzeniem (np. Ga 6,15 i 5,6; 2 Kor 3,10-11; 4,16; 5,17; Ef 2,15; por. Rz 6,4-6; 7,9; 8,1.2.10; Flp 3,6-8; 4,24; Kol 3,9-11; Tt 3,5). 
ST modele zbawcze stanowią dla apostoła drogowskaz, lecz nie matrycę. Podprowadzają one do Chrystusa, lecz nie można ich stosować jako (sztywnego) modelu do zrozumienia objawienia NT, ponieważ wówczas zatraci się nowość Nowego (stanie się on kalką Starego). Zgodnie z zasadą, iż część nie pozwala zrozumieć w takim stopniu funkcji całości, jak całość funkcję części, NT daleko bardziej wyjaśnia ST niż Stary - Nowy (np. żydowskie pojmowanie Mesjasza nie tłumaczy tak dobrze chrześcijańskiego rozumienia, jak chrześcijańskie - starotestamentowe). $Z$ tej racji przy interpretacji myśli Pawła należy bazować w pierwszej kolejności na wypowiedziach NT; wypowiedzi ST mogą jedynie potwierdzać objawienie nowotestamentowe, lecz nie mogą mu narzucać własnego rozumienia (w przeciwnym razie, przykładowo, Mesjasz nie mógłby mieć boskiej natury).

2. Apostoł sprowadza Prawo Mojżeszowe (przykazania) zasadniczo do jednej funkcji: odsłania ono ludzki grzech i mu nie zaradza. Prawo Boże, które w przekonaniu Żyda miało zapewnić mu przystęp do Boga, nie miało takiej mocy. W tej sytuacji Odkupiciel jawi się jako bezwzględnie konieczny. Skupienie się na jednym aspekcie Prawa może wydać się w świetle jego funkcji w ST znacznym uproszczeniem, ale wszystkie inne walory owego Prawa tracą na znaczeniu wobec jego niezdolności zapewnienia człowiekowi tego, czego on najbardziej potrzebuje w sytuacji oddalenia się od Boga, czyli pojednania.

3. Prawdy zbawcze przekazywane przez Pawła nie są komunikowane z naukową precyzją, lecz językiem homiletycznym, tj. zatroskanego o swe wspólnoty pasterza. Nie prowadził akademickich dyskusji, lecz pouczał o drodze do Boga, jaką poznał w Chrystusie. Przykładanie do wypowiedzi apostoła jedynie chłodnej logiki prowadzi do wniosku o nieścisłości jego wypowiedzi czy nawet ich wzajemnym wykluczaniu się ${ }^{11}$. W Pawłowej argumentacji należy uwzględniać pozostałe sfery ludzkiej natury, która jest rozumnym sercem i kochającym rozumem. Dopiero wtedy można pełniej odczytać jego myśl.

Możemy teraz przystąpić do prezentacji podjętego zagadnienia. Przykazania wedle języka ST zostały nakazane przez Boga ${ }^{12}$ (są wyrażone $\mathrm{w}$ trybie rozkazującym - w formie zakazów i nakazów). Zadaniem człowieka jest ich wypełnianie ${ }^{13}$. Funkcja Prawa została spro-

${ }^{11}$ Zob. np. H. Räisänen, dz. cyt.

${ }_{12}$ Zob. G. von Rad, Teologia Starego Testamentu, Warszawa 1986, s. 155-165.

${ }^{13}$ J. D. G. Dunn, Theology, s. 133-137. 
wadzona przez apostoła Pawła do pouczenia człowieka o Bożej woli względem niego $\mathrm{z}$ wynikającymi $\mathrm{z}$ tego konsekwencjami ( $\mathrm{Rz} 3,20 \mathrm{~b}$; $5,20 ; 7,7)$. Z racji że każdy grzeszy, przykazanie stawia każdemu przed oczy jego winę: osądza go i wydaje nań wyrok potępiający $(R z 5,16)$. W świetle przykazań nikt nie znajdzie usprawiedliwienia przed Bogiem (Ga 3,11), spotka się jedynie z Bożym gniewem (Rz 4,15a). Owa nieodwracalnie osądzająca moc Prawa nad człowiekiem została zniesiona dzięki łasce Chrystusa: „nie jesteśmy już poddani Prawu, lecz łasce” (Rz 6,14b i 15).

Stawiamy pytanie o granice bycia niepoddanym Prawu przez chrześcijanina. Czy Chrystus kładąc kres porządkowi religijnemu opartemu na Prawie Mojżeszowym, kładzie również kres temu, co znajdowało się $\mathrm{w}$ sercu owego porządku i stało się jego synonimem, czyli dekalogowi? Postaramy się to ustalić na poziomie chrześcijańskiej nauki i życia - zgodnie z teologiczno-pastoralnym charakterem tej części studium. Pragniemy zatem odczytać myśl apostoła, lecz nie jako naukowca, ale pasterza, który swym adresatom wskazuje drogę do Boga.

\subsection{DUCH WYGASZA FUNKCJĘ STAROTESTAMENTOWYCH PRZYKAZAŃ}

Kiedy popatrzymy na nas samych, przykładnych chrześcijan pozostających pod działaniem Ducha, zauważymy, iż przykładowo przykazanie „Nie zabijaj!” nie odgrywa w naszym życiu więcej roli, jaką spełniało pierwotnie. Jesteśmy pod takim działaniem Ducha Bożego, iż niezależnie od tego, czy istnieje owo przykazanie czy nie, czy myślimy o nim czy nie, Duch Boży wzbudza w nas takie poszanowanie dla cudzego życia, że nawet przez myśl nam nie przejdzie, aby je komuś odebrać. Może pomstujemy na kogoś, lecz nie planujemy zabójstwa. Dzięki życiu Bożemu zaszczepionemu w nas przez Ducha Świętego funkcja przykładowo tego przykazania wygasła względem nas: nie formuje nas ono więcej. Etap życia pod przykazaniem „Nie zabijaj!” mamy za sobą. Jego funkcję przejął zamieszkujący w nas Duch Boży.

W celu zaktualizowania przykazania „Nie zabijaj!” podciąga się dzisiaj pod nie np. szkodzenie własnemu zdrowiu (palenie tytoniu, nadużywanie alkoholu itp.), co nie było jego pierwotną intencją. Fakt aktualizowania tego przykazania potwierdza, że jego pierwotna funkcja zdezaktualizowała się względem znacznej części ludzi. Używając języka 
apostoła, przykazanie „Nie zabijaj!” straciło moc nad nami ${ }^{14}$. Pełni ono jednak nadal swą funkcję względem tych, którzy nie poddali się działaniu Ducha i są zdolni odebrać komuś życie: takim ludziom stale przypomina, że nie mogą tego czynić.

Przykazanie „Nie zabijaj!” ogranicza się do nieodebrania drugiej osobie życia, czyli do absolutnego minimum. My zaś jesteśmy zdolni oddać własne życie za drugich. Myślę, że niejeden z nas byłby w stanie to uczynić. Doskonałość, jakiej udziela w tym zakresie Duch (o tym szerzej w kolejnym podpunkcie), wyraźnie przewyższa wymóg przykazania „Nie zabijaj!”. Duch uzdalniając do więcej, niż wymaga samo przykazanie, „wygasza” jego dotychczasową funkcję. Dlaczego? Kto bowiem jest zdolny oddać własne życie za drugich, nie odbierze go nikomu. Tym samym nie potrzebuje pouczenia, że nie wolno zabijać ${ }^{15}$. Nie kieruje nim przykazanie, lecz miłość bliźniego. Gdyby kierowało nim samo przykazanie, nie byłby zdolny oddać swego życia za drugą osobę. Względem kogoś takiego funkcja przykazania „Nie zabijaj!” wygasła. Jeżeli potrzebuje jakiegoś pouczenia, to jedynie tego, aby jeszcze mocniej kochać bliźnich. To, co powiedziałem w związku z przykazaniem "Nie zabijaj!", odnosi się także do pozostałych. Ustanie funkcji przykazań ma charakter personalny - podobnie jak Boże działanie w człowieku. Nie jest to usunięcie danego przykazania z życia społeczeństwa (kościołów, modlitewników itp.), lecz ustanie jego funkcji w przypadku konkretnych osób $^{16}$. Ową funkcję przejmuje udzielony Duch.

\subsection{DUCH WYDOSKONALA TREŚĆ STAROTESTAMENTOWYCH PRZYKAZAŃ}

Na przykładzie gotowości do oddania z miłości życia za drugich (nie musi być to związane jedynie z chrześcijaństwem) widać, że Duch Boży uzdalnia do więcej niż wymaga od nas przykazanie "Nie zabijaj!”. W tym „więcej” (miłowanie bliźnich) zawiera się owo „mniej” („Nie zabijaj!"), lecz to pierwsze, a nie drugie kieruje naszymi poczynaniami.

14 Rz 6,14-15; Ef 2,15.

15 Wyobraźmy sobie Matkę Teresę z Kalkuty czy Jana Pawła II, którym za ich ziemskiego życia przypominamy: „Pamiętaj, abyś nikogo nie zabił(a)!”.

${ }^{16}$ Owo ustanie funkcji przykazań ma także wymiar eklezjalny, czyli wspólnotowy, ponieważ owe jednostki tworzą wspólnotę Kościoła. Dar Ducha uobecnia się na poziomie personalnym, realizuje się w pojedynczych osobach, i eklezjalnym, ponieważ razem tworzą one Kościół. 
Duch przejął funkcję przykazania „Nie zabijaj!” i tym samym wygasił instruującą rolę przykazania: kto bowiem kieruje się miłością bliźniego, de facto nikogo nie zabija. Temu, kto biegle czyta, nie potrzeba przypominać liter alfabetu. Nie wraca on do elementarza, ale też nie zaprzecza zawartym w nim treściom i temu, że może być on pomocny uczącym się czytać. Analogicznie przedstawia się sprawa z przykazaniami. Duch nie wygasza treści przykazań, lecz ich funkcję - treść wydoskonala.

Staje się to bardziej oczywiste, kiedy odwołamy się do chrześcijańskich świętych. W wyniku głębokiego zjednoczenia z Duchem Bożym oni w jeszcze mniejszym stopniu od nas potrzebowali przykazań, ponieważ goszczący w nich Duch Chrystusa uzdalniał ich do znacznie doskonalszego postępowania, niż wymaga tego ich treść. Heroizm ich życia wielokrotnie przewyższał wymagania przykazań ${ }^{17}$. Podobnym przykładem są chrześcijańscy mistycy. Wszyscy oni postępowali zgodnie z tym, co mówią przykazania, lecz o relacji z Chrystusem nie wyrażają się w kategoriach przykazań, lecz oblubieńczego, miłosnego zjednoczenia. Kategoria „przykazanie” nie była więcej adekwatna do rodzaju ich relacji z Bogiem. Etap życia „pod przykazaniami” jako przewyższony w oblubieńczym zjednoczeniu z Chrystusem mieli za sobą. Oblubieńcze zjednoczenie mistyków z Panem doskonale obrazuje nowotestamentową relację z Bogiem. Nie jest to kierowanie się w życiu nakazującymi coś przepisami, lecz miłością do Chrystusa.

Apostoł Paweł z racji niezdolności przykazań do zapewnienia nam przystępu do Boga sprowadził je do litery Prawa, która zabija (2 Kor 3,6): pouczają o tym, jak należy postępować przed Bogiem, lecz z racji, że każdy je łamie, ściągają wyrok potępiający (Rz 4,15a). W świetle przykazań każdy jawi się jako grzesznik zasługujący jedynie na Boży gniew. My dzisiaj inaczej postrzegamy przykazania, tj. w ścisłej relacji z łaską Chrystusa, która działa również poprzez nie i prowadzi do zbawienia. Przykazania zostały schrystianizowane i nadano im nową funkcję. Lecz tej funkcji nie możemy nanosić na ST i na ich rozumienie przez apostoła Pawła, który rozpatrywał przykazania z punktu widzenia Żyda, widzącego w nich środek zapewniający przystęp do Boga. Dlatego odpowiedź apostoła brzmi: na tym polu są one całkowicie bezsilne. Lecz przykazania nie tylko nie są w stanie zapewnić grzesznikowi przystępu do Boga, ale stawiając mu przed oczy grzechy, potępiają go. Relacja z Bogiem oparta

17 Św. Ojciec Pio miał wyznać, że w życiu tylko raz ciężko zgrzeszył, tj. skłamał (F. Castelli, Przestuchanie Ojca Pio. Odtajnione archiwa Watykanu, Kraków 2009). 
na przykazaniach, czyli bez Chrystusa, jest beznadziejna, gdyż bez wyjścia. Dlatego bez Chrystusa są one literą, która zabija.

Pozostający zaś pod działaniem Ducha Bożego nie czczą obcych bogów, szanują rodziców, nie zabijają, nie cudzołożą, nie kradną itd. Wypełniają wszystko, co mówi dekalog (i jeszcze więcej), lecz do takiego postępowania nie motywuje ich dekalog. Nauczyli się już jego wymogów i przeszli do wyższej klasy. A w tej wyższej klasie dowiedzieli się o przykazaniu miłości względem wszystkich. Dlatego w nowej rzeczywistości zbawczej Jezus daje nowe i jedno przykazanie, przykazanie miłości (J 13,34; por. Mk 12,29). Duch wprowadził nas na wyższy i doskonalszy poziom życia z Bogiem i otrzymujemy adekwatne do tego poziomu pouczenie: miłować każdego. Względem dekalogu wymaga się obecnie od nas więcej. Do wypełnienia przykazania miłości bliźniego nie wystarczą dotychczasowe przykazania, jak „Nie zabijaj!”. Ktoś może je wypełniać i jednocześnie nienawidzić drugą osobę. Dlatego nie jesteśmy więcej formowani przez dekalog, bo się go już nauczyliśmy, lecz przez przykazanie miłości, które stawia przed nami nowe wyzwanie. A jest to prawdziwe wyzwanie. Nie sprawia nam bowiem żadnej trudności niezabicie kogoś, lecz sprawia dużą trudność miłowanie każdego. Zachowywanie przykazań dekalogu potwierdza, że prowadzi nas Duch Boży, lecz Jego moc objawia się w pełni w miłowaniu bliźnich.

W Rz 13,9-10 i Ga 5,14 czytamy, że całe Prawo wypełnia się w przykazaniu miłości bliźniego. W przypadku Rz apostoł wyjaśnia, że kto miłuje bliźniego, nie zabija go, nie zdradza, nie okrada, innymi słowy nie wyrządza mu żadnej krzywdy. Według Pawła miłość wystarcza do wypełnienia całej woli Bożej. Miłość bliźniego wygasza tym samym instruującą funkcję przykazań: nie czynię bliźniemu krzywdy, ponieważ go kocham, a nie dlatego, że zabrania mi tego przykazanie. Kto opiera swe życie jedynie na przykazaniach dekalogu, nie jest zdolny odpowiedzieć na wezwanie Jezusa do miłowania nieprzyjaciół (Mt 5,44) i tym samym przynależy do rzeczywistości starotestamentowej. Jeżeli zasadę miłości bliźniego zastąpimy koncepcją przykazania, to stajemy przed koniecznością bezustannego precyzowania, co wolno, a czego nie wolno. Skutkiem tego może być kazuistyka: setki uściślających przepisów - i stale niewystarczających, ponieważ życie wciąż przynosi nowe problemy. $Z$ racji jednak, że nie wszyscy są zdolni do prawdziwej miłości bliźniego, przykazania w sensie podstawowych wytycznych, lecz nie setek przepisów, spełniają nadal swą pożyteczną role w życiu Kościoła. 


\subsection{DUCH, KTÓRY NIE NAKAZUJE, LECZ POCIĄGA KU ŻYCIU ZGODNEMU Z WOLĄ BOŻĄ}

Przykazania stale mówią nam to samo: dziesięć lat temu, rok temu, wczoraj, dzisiaj: raz je wypełniamy, a innym razem łamiemy. Gdyby od nich zależało życie zgodne z wolą Bożą, to raz je przyjąwszy, nigdy byśmy ich nie przekroczyli. Wiemy jednak, że tak nie jest. Nie ma w nich mocy do ustrzeżenia nas przed grzechem. Udzielony zaś Duch, Boża łaska, ma moc ustrzec przed grzechem ${ }^{18}$. Duch czyni to w ten sposób, że wzbudza $\mathrm{w}$ nas upodobanie $\mathrm{w}$ tym, co Boże. Tym samym zło przestaje się nam wydawać atrakcyjne. Bardziej pociąga nas to, co zgodne z Bożą wolą. W tym duchu apostoł radzi Galatom: pozwólcie się prowadzić Duchowi Bożemu, a nie spełnicie uczynków ciała (Ga 5,16 i 18). Nie pisze im: weźcie za przewodnika dekalog, lecz pozwólcie się prowadzić Duchowi. Można sformułować następującą zasadę: im więcej w nas Chrystusa, czyli Ducha Bożego, tym lepiej żyjemy ${ }^{19}$. Poziom życia moralnego nie zależy od mnożenia przykazań, lecz od zjednoczenia z Bogiem. I to w tę stronę należy zmierzać.

Poddanie się Duchowi Bożemu sprawia, że życia wedle norm moralnych nie odbieramy jako przymusu (nakaz) i ograniczenia własnej wolności, gdyż dzięki Duchowi z radością wybieramy dobro (jawi się nam jako bardziej atrakcyjne). Dzięki udzielonemu Duchowi z życia chrześcijanina znika przymus i nadzór formułowanych przez wieki norm postępowania. Duch Boży wzbudza w nas upodobanie w tym, co Boże i ku temu pociąga. Kogoś takiego nie trzeba kontrolować: niezależnie od istnienia czy nieistnienia nakazów czy zakazów, dzięki obecnemu w nim Duchowi Bożemu wybierze on to, co zgodne z wolą Bożą. Ten stan apostoł określa życiem w wolności dzieci Bożych: „gdzie Duch Pański - tam wolność" (2 Kor 3,17b). Gdzie nie ma Ducha Bożego, tam na straży właściwego postępowania stoją nakazy i zakazy. Pod nadzorem i rygorem różnych rozporządzeń żyją jednak słudzy czy niewolnicy, lecz jest to stan niegodny synów Bożych.

${ }^{18}$ Zdajemy sobie sprawę z ułomności ludzkiej natury i jej skłonności do grzeszenia. Przez powyższe stwierdzenie rozumiemy znaczne ograniczenie złych czynów, jak wyeliminowanie z życia ciężkich grzechów.

${ }^{19}$ Instrukcja PKB pt. Biblia a moralność. Biblijne korzenie postępowania chrześcijańskiego, pkt 55. 
Przejęcie i wydoskonalenie starotestamentowej funkcji przykazań przez Ducha Bożego oznacza, że chrześcijanin w swym życiu nie kieruje się nakazującymi mu coś przepisami, lecz tym, co poprzez jego sumienie (uformowane też przez przykazania) podpowiada mu Duch i ku czemu go pociąga. Sumienie ukształtowane przez Ducha Bożego odgrywa tu decydującą rolę ${ }^{20}$. O tym, czy postępuję niezgodnie z wolą Bożą, nie decyduje ostatecznie przykazanie, lecz sumienie. Chrześcijanin jest pouczany od wewnątrz - nie przez wyryte w kamieniu zapisy (por. 2 Kor 3,7). Tę nową zasadę życia moralnego apostoł Paweł wyraża w znanym stwierdzeniu: „Mając życie od Ducha, postępujmy według Ducha!” (Ga 5,25). Źródłem życia moralnego jest dla chrześcijanina zamieszkujący w nim Duch Boży. Apostoł tylko raz mówi o potrzebie zachowywania przykazań Bożych (1 Kor 7,14). W swym nauczaniu moralnym pozostaje konsekwentny: skoro zasadą Bożego życia jest Duch, to właściwe postawy moralne można osiągnąć dzięki Duchowi, a nie przykazaniom. Dlatego o swych adresatach pisze, że są prowadzeni przez Ducha Bożego (Rz 8,14), że mają rozpoznać w Duchu to, co dobre (1 Kor 2,12.15a), że mają badać siebie, ponieważ Duch Chrystusa jest w nich (2 Kor 13,5), że z pomocą Ducha mają dążyć do prawdziwej sprawiedliwości (Ga 5,5), że mają się poddać kierownictwu Ducha Bożego (ww. 16 i 18), czy że w życiu mają się kierować chrześcijańską miłością, której źródłem jest Duch Boży (Rz 14,19; 15,2.5; 1 Kor 10,24.33; 16,14; Flp 1,9-10; Ef 5,1-2). Wzorem postępowania jest Chrystus (1 Tes 1,6-7; Kol 1,10; 2,6-7; Ef 5,1-2), czy nawet Paweł (Flp 3,17), lecz nie dekalog. Wobec jednej zachęty do zachowywania przykazań, rysuje się wyraźnie dominująca zasada moralnego postępowania według Pawła, tj. udzielony Duch, który objawia się $\mathrm{w}$ miłości. Skutkiem postaw przeciwnych jest zasmucanie Ducha Bożego (Ef 4,30). Konsekwentnie, życia chrześcijanina apostoł nie weryfikuje w świetle przykazań, lecz owoców Ducha i ciała (Ga 5,22-23 i 19-21). Paweł posługuje się nowym językiem, adekwatnym do nowej rzeczywistości zbawczej. Język przykazań jest językiem starotestamentowym. Można się nim posługiwać w chrześcijaństwie, lecz nie powinien on wysuwać się przed model życia w Duchu.

Wyższość życia w Duchu uwidacznia się w różnych sytuacjach życiowych. Zdarzają się takie, w których nie wiemy, jak postąpić, ponieważ żadne ze znanych nam przykazań nie reguluje zaistniałej sytu-

${ }^{20}$ Zob. A. Derdziuk, Teologia moralna w stużbie wiary Kościoła, Lublin 2010, s. $54-58,175-177$. 
acji. Spotykamy się z tym stale, ponieważ życie ciągle nas wyprzedza i przynosi nowe dylematy (np. w bioetyce). Czy do chwili sformułowania nowej zasady postępowania mamy żyć w jakiejś pustce moralnej? Nie. Wprawdzie możemy szukać rady u duszpasterza czy czekać na rozstrzygnięcie Nauczycielskiego Urzędu Kościoła, lecz każdy chrześcijanin, żyjący $\mathrm{w}$ głębokim zjednoczeniu z Duchem Bożym, od razu wybierze właściwe rozwiązanie, ponieważ podpowie mu je goszczący w nim Duch Chrystusa. Może nie będzie umiał uzasadnić swego wyboru, lecz dokona właściwego. W głębi swej duszy znajdzie właściwą odpowiedź. Nie musi zatem czekać na rozstrzygnięcie Magisterium Ecclesiae. Inaczej zbawcze działanie Boga w świecie zostałoby zinstytucjonalizowane, a udzielony Duch odgrywałby drugorzędną rolę. Duch poprzez nasze sumienie pozwala w każdej sytuacji wybrać od razu to, co zgodne z wolą Bożą. Rozstrzygnięcie Magisterium Kościoła potwierdzi jedynie i uzasadni wcześniejszy wybór. Taki chrześcijanin przyjmie je z radością jako potwierdzenie tego, co już wcześniej myślał.

Zamieszkujący w chrześcijaninie Duch Boży staje się dominującą zasadą postępowania zgodnego z wolą Bożą. Nikt nie powie, że przykazania mogą nami pokierować lepiej od Ducha Bożego. Przykazania nie mają przede wszystkim mocy nami pokierować; one jedynie informują, co jest zgodne, a co niezgodne z wolą Bożą. Motywacja do życia zgodnego z wolą Bożą - w przypadku każdego człowieka, tj. chrześcijanina, Żyda czy muzułmanina, szczerze pragnącego żyć uczciwie - płynie od zamieszkującego w nas Ducha Bożego. Wystarczy zwrócić uwagę na to, jak wiele osób zna przykazania (większość), a ich nie zachowuje. To, że postępujemy zgodnie z wolą Bożą, nie jest zasługą przykazań, lecz łaski.

Czy życie „w Duchu” nie wypiera w jakimś sensie norm moralnych? Wręcz przeciwnie! - prowadzi do jeszcze gorliwszego postępowania $\mathrm{w}$ zgodzie $\mathrm{z}$ nimi. Lecz $\mathrm{z}$ tą różnica, że motywacja do takiego postępowania nie płynie z przykazań. Sam Duch Boży nami kieruje i pobudza do życia $\mathrm{w}$ doskonałym zjednoczeniu $\mathrm{z}$ Bogiem. Ktoś pod działaniem Ducha czyni więcej niż wymagają od niego przykazania. Sprawdza się to na wspomnianym przykładzie życia świętych.

Apostoł Paweł zmierza do wniosku, że kto trwa w Chrystusie, wypełnia wszystko, czego Bóg od niego oczekuje. Przykazania niczego nie dodają tej relacji ani jej nie wydoskonalają - nie są w stanie, gdyż życie „W Duchu" przewyższa życie wedle wszelkich innych zasad. Z Duchem Chrystusa otrzymujemy więcej niż dekalog, więcej niż Pięcioksiąg, więcej niż pouczenia proroków i rady mędrców. Apostoł głosi prymat osobo- 
wej relacji z Chrystusem i tworzonej z Nim wspólnoty jako podstawy chrześcijańskiego życia. Ilustruje to własnym przykładem: „Teraz zaś już nie ja żyję, lecz żyje we mnie Chrystus" (Ga 2,19). Nie jest to życie, u którego podstawy stoją przykazania, lecz osobowa relacja z Chrystusem. W apostole zagościł Chrystus i to On kieruje jego życiem ${ }^{21}$. On, który świetnie znał Pisma i skrupulatnie wypełniał wcześniej zapisy ST (Flp 3,6b), w Chrystusie odkrył nową jakość życia z Bogiem. W związku z tym pisze: „dlatego teraz możemy pełnić służbę $\mathrm{w}$ nowym duchu, a nie według przestarzałej litery" (Rz 7,6).

Życie wedle przykazań jest pierwszym etapem chrześcijańskiego życia i znakiem niedojrzałości relacji z Bogiem (elementarz). Czas pełnoletności charakteryzuje życie "w Duchu”. Jest to czas bycia synami Bożymi, którzy nie czynią czegoś dlatego, że przepis tak nakazuje i jeszcze może z lęku przed karą, ale ożywieni Duchem Bożym wybierają z radością to, co zgodne z wolą Bożą. Jest to stan pełnej wolności w Bogu: „Ku wolności wyswobodził was Chrystus” (Ga 5,1a). Wolność polega na wybieraniu tylko dobra. Kto wybiera zło, staje się niewolnikiem grzechu. Pełnia wolności nie polega na możliwości wybierania między dobrem a złem. Dopóki mamy taką możliwość, nie jesteśmy w pełni wolni, ponieważ zawsze istnieje możliwość wybrania zła i utraty wolności (przez stanie się niewolnikiem grzechu). Dlatego pełną wolność osiągamy wtedy, kiedy wybór zła nie wchodzi w grę. Duch Boży prowadząc nas jedynie ku dobru, prowadzi ku pełnej wolności.

\subsection{KONSEKWENCJE POSTRZEGANIA RELACJI Z BOGIEM PRZEZ PRYZMAT PRZYKAZAŃ}

Zwrócimy uwagę na negatywne strony starotestamentowego myślenia wedle przykazań. Przykazanie rozumiane od czasów ST jako zobowiązanie, a tym samym zgodnie ze swą naturą zawsze kojarzone z konsekwencjami za jego przekroczenie w postaci kar, siłą rzeczy kształtuje świadomość nakazu i rozliczenia. $W$ ten właśnie sposób jest często postrzegana przez chrześcijan relacja z Bogiem. Ludzie odbierają przykazania jako nakaz. Nakaz zaś ciąży. Za jego złamanie grożą określone kary. To z kolei prowadzi do postrzegania Boga jako sędziego, który rozlicza

${ }^{21}$ R. N. Longenecker, dz. cyt., s. 92-94. 
nasze czyny, a nie jako Ojca. Mamy tu ciąg konsekwencji wynikających z częstszego posługiwania się koncepcją staro- niż nowotestamentową.

W rezultacie uczynienie czegoś złego budzi w ludziach $\mathrm{w}$ pierwszej kolejności lęk, ponieważ za naruszenie pewnej normy grożą określone kary. Przykazanie, jak każdy nakaz czy zakaz, kształtuje świadomość bycia rozliczanym z własnych czynów. Kiedy zrobię coś złego, pojawia się lęk przed konsekwencjami. Lęk wprowadza zaś dystans i utrudnia pojednanie. Unikamy tych, których się lękamy. Ludzie mówią nieraz: nie wyznaję grzechów, bo lękam się, czy Bóg mi je wybaczy. Czyniąc zaś coś złego, nie powinienem odczuwać w pierwszej kolejności lęku przed karą, lecz żal, że sprawiłem przykrość. Na twarzy pojawiają się łzy, a nie strach. Odczuwanie skruchy, żalu prowadzi od razu do pojednania: chcemy czym prędzej naprawić wyrządzoną krzywdę, aby druga strona nie cierpiała. Ale do tego trzeba widzieć w Bogu Ojca, a nie sędziego. Strach świadczy o relacji: pan - sługa, a nie ojciec - syn / córka. Boga nie należy się bać, lecz kochać.

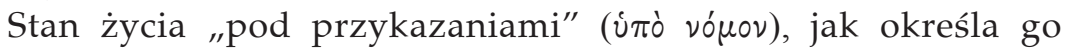
apostoł Paweł, może obowiązywać tylko przejściowo - uwłacza bowiem godności dziecka Bożego. Kiedy w Ga apostoł stwierdza, że nie podlegamy więcej nadzorowi Prawa, przytacza tylko jeden argument, tzn. że w Chrystusie staliśmy się synami Bożymi (3, 24-26). W przypadku synów i córek niczego się nie wymusza, ponieważ nakaz pogwałca wolność i czyni z dzieci sługi czy niewolników. Względem dzieci cel osiąga się w inny sposób. Przekonuje się je i wzbudza upodobanie ku temu, co dobre. W przypadku relacji z Bogiem owo upodobanie wzbudza w nas Duch Boży. Goszcząc w nas, upodabnia nasze pragnienia do „pragnien”" Boga. Wypełnianie woli Bożej dzięki udzielonemu Duchowi wprowadza już obecnie w rzeczywistość nieba, w której Duch będzie - podobnie jak teraz - zasadą postępowania zgodnego z wolą Bożą, lecz z racji pełnego zjednoczenia z Bogiem owocem Jego działania będzie całkowite przylgnięcie do Bożej woli. W niebie nikogo nie trzeba strofować czy pouczać o właściwym postępowaniu, a jest to wynikiem pełnego zagoszczenia w zbawionych Ducha Bożego. W niebie nie będzie przykazań lub pouczeń w stylu: „Tego ci nie wolno!", „Tamtego ci nie wolno!” czy „Masz zrobić tamto, a jeżeli nie posłuchasz, zostaniesz ukarany”. W przeciwnym razie odbieralibyśmy niebo jako bezustanny przymus i ograniczanie naszej wolności. Duch Boży rozbudzi w nas takie pragnienie tego, co Boże, że Bóg stanie się jedynym upragnionym dobrem. Lecz ów stan został już zainicjowany z chwilą wylania Ducha Świętego. Potwierdzają to poucze- 
nia moralne apostoła Pawła, w których odwołuje się on do udzielonego Ducha i okazjonalnie do przykazań.

Wzrastająca liczba „niepraktykujących” dowodzi małej atrakcyjności chrześcijaństwa w ich oczach, które z powodu uproszczonego w niektórych obszarach nauczania zostało w jakiejś mierze odarte ze swej głębi. Postrzeganie relacji z Bogiem przez pryzmat zobowiązań wyrażonych w przykazaniach, jak w ST, zostało przewyższone w Chrystusie - w życiu w zjednoczeniu z Duchem Bożym. Jest to nowy porządek zbawczy, który kładzie kres staremu. Z ambony słyszymy jednak częściej o konieczności zachowywania przykazań niż o darze Ducha, który uzdalnia do ich zachowania i do życia ponad ich wymogi. Niestety korzystamy częściej z modelu staro- niż nowotestamentowego.

Nakreśliłem sytuację optymalną, czyli model nowego życia, w jakie wprowadził nas Jezus. Życie, jakie kreśli apostoł, stanowi ideał. Wiemy jednak dobrze, że nie wszyscy żyją w głębokim zjednoczeniu z Duchem Bożym. Trzeba zatem wyraźnie powiedzieć, że pouczenia prawa moralnego w postaci wyrytej w kamieniu pozostają nadal w mocy względem tych, w których jest mniej Ducha Bożego. Potrzebują oni elementarza. W ich przypadku sprawdza się odwrotność wcześniejszej zasady: im mniej w kimś Ducha Bożego, tym więcej potrzebuje przykazań, pouczeń. Jeżeli nie prowadzi go Duch Boży, to prowadzą go przykazania, które nakazują i rozliczają.

Można wysunąć zarzut, że pomimo daru Ducha Świętego chrześcijanie nie przestali ciężko grzeszyć. Jest to smutną prawdą, dowodząca, że zamiast wygaszać funkcję przykazań, wygaszamy w sobie działanie Ducha. W wyniku takiego procesu obserwujemy ogromne zmaganie się chrześcijan z wymogami podstawowych przykazań. Diagnoza tego stanu jest prosta: wygasili oni w sobie żar Ducha Świętego i muszą teraz sami stawić czoła ich wymogom, a to zawsze kończy się ich poważnym naruszeniem. Lecz nie wyrwą się z tego stanu przez przypominanie im o przykazaniach, gdyż już je znają, ale przez ożywienie w sobie Bożego życia. Duch wzbudzi w nich upodobanie ku temu, co Boże i z radością będą kroczyli drogą zgodną z wolą Bożą. W konsekwencji będą żyli w wolności dzieci Bożych. Sinusoida dobra i zła w naszym życiu nie jest związana z przykazaniami, gdyż one stale mówią to samo, lecz ze stopniem życia Bożego w nas, które ulega wahaniom.

$\mathrm{Na}$ zakończenie zwrócę uwagę na bardzo znamienny fakt, iż według tradycji Łukaszowej wylanie Ducha Świętego miało miejsce w żydowskie święto Pięćdziesiątnicy (Dz 2,1-4). Owo zaś święto upamięt- 
niało nadanie Prawa na Synaju. Nie jest to przypadek. Duch przejmuje i wydoskonala funkcję przykazań.

Streszczenie: Artykuł dotyczy Pawłowych wypowiedzi na temat końca Prawa Mojżeszowego. Autor jest zaiteresowany praktycznym zastosowaniem tych wypowiedzi, tj. w chrześcijańskim życiu. Studium ukazuje, że zesłany Duch wygasza przykazania - ich funkcję, lecz nie ich treść, którą to udoskonala. Przeciwnie do Starego Testamentu Duch jest tym, który prowadzi chrześcijan.

Słowa kluczowe: Prawo Mojżeszowe; przykazania; Duch Święty; życie chrześcijańskie.

Abstract. Does the given Spirit put aside the Commandements? A contribution to Paul's pneumatology. The paper concerns Paul's statements about the end of the Mosaic Law. The author is interested in practical application of these statements, i.e. in Christian life. The study reveals that the given Spirit puts aside the commandments - their function, but not the content whom He brings to perfection. Contrary to the OT it is the Spirit who guides the Christians.

Keywords: The Mosaic Law; commandments; The Holy Spirit; Christian life. 